\title{
ЯЗЫКОЗНАНИЕ
}

UDC 811.432.615

\section{A Description of Dzə (Jenjo) Nouns and Noun Phrases, an Adamawa Language of Northeastern Nigeria}

\author{
P. Benson \\ Federal University Wukari, \\ PMB 1020, Katsina-Ala Road, Wukari, Taraba State, Nigeria
}

For citation: Benson P. A Description of Dzə (Jenjo) Nouns and Noun Phrases, an Adamawa Language of Northeastern Nigeria. Vestnik of Saint Petersburg University. Asian and African Studies, 2020, vol. 12, issue 4, pp. 490-504. https://doi.org/10.21638/spbu13.2020.402 (In Russian)

Dzo [jen] is an Adamawa language spoken in some parts of Taraba, Adamawa and Gombe states in Northeastern Nigeria. The study presented in the article syntactically describes nouns and noun phrases in Dzə. In an attempt to document Dzə and taking into consideration that Dzo is an under-investigated and under-documented language, the result will provide important data to typological research and to linguists working on Adamawa languages. The study adopts a descriptive research design in collecting, describing and analyzing the data. The data was obtained from fieldwork in December 2014, personal observations of daily conversations, introspection and the Dzo Bible. In the article, a brief overview of the phonology and tone of Dzo is provided. It also shows the different kinds of nouns, pronouns and noun phrases in Dzə; simple and complex noun phrases. The language is rich in pronouns, consisting of subject pronouns, object pronouns, reflexive pronouns, interrogative pronouns and possessive pronouns. As it is with most African languages, the elements that constitute a noun phrase occur after the head noun. These elements are articles, demonstratives, possessives, adjectives, numerals, quantifiers, genitive constructions (inalienable and alienable possessives) and relative clauses. This is a preliminary study of Dzə and it is open for further research and contributions.

Keywords: Dzə, nouns, noun phrases, Jenjo, Adamawa.

\section{Introduction}

Dzə [jen] is an Adamawa language spoken in some parts of Adamawa, Taraba and Gombe States, Northeastern Nigeria. The original name of the language is Dzo but it is widely known as Jenjo. It is a minority language that belongs to the poorly studied Adamawa languages. Its speakers are predominantly in Jen (their capital home), Karim-Lamido local government area of Taraba State. The number of Dzo speakers is also not yet known.

() Санкт-Петербургский государственный университет, 2020 
With this in mind, there is a need to describe the minority languages in Nigeria especially those of Northeastern Nigeria so as to prevent them from dying.

According T. Givón, nouns in any language includes words that express the most time-stable concepts, e.g. rock, tree, mountain, house etc [1, p. 51]. E. T. Payne further states that to determine whether any given word is a noun or not, one must first determine the morphosyntactic characteristics of prototypical nouns. Then the grammatical category of a questionable word can usually be determined according to how closely the word follows the morphosyntactic pattern of prototypical nouns [2, p. 33]. However, there will always be some truly ambiguous examples as well as words that function sometimes as a verb and sometimes as a noun depending on the context. There is also the issue of nominalization. For example, in Dzə ' $i$ ' is a nominal marker which turns verb into noun lébí is 'sing' ilébí is 'singer'. Their idea is prescriptive rather than descriptive. On the other hand, A. Radford states that a noun phrase is a phrase whose head is a noun, for example a structure such as "The king of Utopia" is a noun phrase comprising the head noun "king", the complement "of Utopia" and its specifier (determiner) "the". Therefore, noun phrase is a phrase consisting of a noun and other dependents and the noun serving as the head of the phrase [3, p. 87]. This study describes the nouns and noun phrases in Dzə. The study adopts descriptive research design in collecting, describing and analyzing the data. The sections that follow describe the phonology, tone and noun phrases in Dzə.

\section{The phonology of Dzo}

\section{Consonants}

According to N. K. Othaniel, there are 33 consonant phonemes in Dzə language [4]. The consonant phonemes are symmetrical in terms of voicing. These consonant phonemes are shown in the table 1 below.

Table 1. Dzə consonant sounds

\begin{tabular}{|c|c|c|c|c|c|c|c|c|}
\hline & bilabial & $\begin{array}{l}\text { labio } \\
\text { dental }\end{array}$ & alveolar & $\begin{array}{l}\text { post } \\
\text { alveolar }\end{array}$ & palatal & $\begin{array}{l}\text { labio } \\
\text { velar }\end{array}$ & velar & glottal \\
\hline plosive & $\mathrm{pb}$ & & $\mathrm{td}$ & & $c_{J}$ & $\widehat{\mathrm{kp}} \mathrm{gb}$ & $\mathrm{kg}$ & \\
\hline affricate & & & $\widehat{t s} \widehat{\mathrm{dz}}$ & $\widehat{t} \int \sqrt{3}$ & $\mathrm{n}$ & & n & \\
\hline nasal & $\mathrm{m}_{0} \mathrm{~m}$ & & $\mathrm{n}$ & & & & & \\
\hline fricative & & $\mathrm{fv}$ & s z & $\int 3$ & & & $M$ & $\mathrm{~h}$ \\
\hline approximant & & & 1 & & $\begin{array}{c}j \mathrm{jj} \\
\text { प⿺ }\end{array}$ & $\mathrm{w}$ & & \\
\hline
\end{tabular}

\section{Vowel}

The vowel inventory of Dzə consists of nine distinct oral vowels, seven nasalized vowels and six breathy vowels (Table $2-4$ ). 
Table 2. Oral vowels

\begin{tabular}{|l|c|c|c|c|c|c|c|}
\hline & \multicolumn{2}{|c|}{+ ATR VOWELS } & \multicolumn{5}{|c|}{-ATR VOWELS } \\
\hline & front & central & back & front & central & back & \\
\hline close & $\mathrm{i}$ & & $\mathrm{u}$ & & $\mathrm{i}$ & & \\
\hline mid & & & & & $\partial$ & & \\
\hline & $\mathrm{e}$ & & $\mathrm{o}$ & $\varepsilon$ & & 0 & \\
\hline open & & & & & $\mathrm{a}$ & & \\
\hline
\end{tabular}

Table 3. Nasalized vowels

\begin{tabular}{|l|c|c|c|}
\hline & front & central & back \\
\hline close & $\tilde{1}$ & $\tilde{i}$ & $\tilde{\mathrm{u}}$ \\
\hline mid & & $\tilde{a}$ & \\
\hline & $\tilde{\varepsilon}$ & & $\tilde{\jmath}$ \\
\hline open & & $\tilde{a}$ & \\
\hline
\end{tabular}

Table 4. Breathy vowels

\begin{tabular}{|l|c|c|c|}
\hline & front & central & back \\
\hline close & $\mathrm{i}$ & & $\underline{u}$ \\
\hline & $\mathrm{e}$ & & 0 \\
\hline mid & & g & \\
\hline open & & $\mathrm{a}$ & \\
\hline
\end{tabular}

\section{Tone}

The Dzə language has contrastive three level tone: H, M, L. example: H: bí 'song', M: $b \bar{i}$ 'metal' L: bì 'word'. There are also two contrastive contour tones which are H/L, H/M, $\mathrm{M} / \mathrm{L}, \mathrm{H} / \mathrm{R}, \mathrm{L} / \mathrm{R}, \mathrm{M} / \mathrm{R}$.

\section{Nouns and Pronouns}

Nouns may be derived from verbs by using the nominalizer prefix $-i$. Most of the derived nouns refer to doer. See table 5 below. Detailed description of nominalisation is not relevant here. Here are the examples.

Table 5. Nominalized Form

\begin{tabular}{|c|c|c|c|}
\hline Verb & Gloss & Nominalized form & Gloss \\
\hline tenwá & announce & i-tènwá & announcer \\
\hline tsàki & mourn & $i-t s \grave{k} i$ & mourner \\
\hline dzàwé & travel & 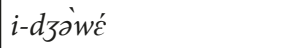 & traveller \\
\hline lé & $\operatorname{sing}$ & i-lébí & singer \\
\hline ब大a & buy/sell & i-dzว̀-nìn & buyer \\
\hline
\end{tabular}


The following section describes the different types of nouns in Dzo.

\section{Proper Names (Nouns)}

"proper names are nouns that are used to address and identify particular persons or culturally significant personages or places" [2, p.39]. Examples of such nouns in Dzo are:

(1) a. Place: Dzə 'Jen', Bwè, Nwàká, Tànkə,'names of villages around Jen' Mìn Binuwe, 'River Benue' Min Taraba "River Taraba".

b. Person: Fillah 'Fillah', Filalo, Fijamilo, Kanmila "these are all common names of Dzə people.

\section{Count and Mass Nouns}

Count nouns refer to things that can be counted and mass nouns refer to substances like water, sand, air and wood [2, p. 41]. The plural form of count nouns in Dzo are marked by the plural marker ' $e$ ' examples are: $y \varepsilon \dot{\varepsilon}$ 'chicken' $e-y \grave{\varepsilon}$ 'chickens', y' 'pig' e-yo 'pigs', idzwa 'dog' e-idzwà 'dogs', pīsahú 'school', e-pīsahú 'schools', nìnpú 'goat' e-nìnpu' 'goats'. Examples of mass nouns are nìmmari 'rice', nìnyi beans, mìn water and hywà sand kántúy 'sugar' nywi 'oil' tfúkwé 'salt' and more below. The following comes either under the count nouns or mass nouns.

\section{Common Nouns}

General names of place, person and thing. They are not capitalised. Examples are:

(2) a. Place: hywà 'country' (Lit. land), lòmwé 'market', kwàfi 'church', pīpinwà 'place of worship', pīpakú 'mosque'.

b. Person: ivò 'king', $k l \supset$ 'king maker' ifft 'person/human'.

c. Thing: nìbinhhu 'animal', nwàkávà 'clan' ví 'day', dàró ‘book, hú 'grass', ká 'tree.

\section{Concrete Nouns}

Names of persons, places and things that are tangible with one or more of the senses.

(3) a. Person: ibwét 'man', ijè 'woman' imwà 'child', inẵft 'elder' itwè 'owner/lord'.

b. Place: fànín 'farm', pisahu 'school'.

c. Thing: bi 'metal', mambin 'frog' fjó 'pocupine', fi 'crocodile', lwēy 'canopy'.

\section{Abstract Nouns}

Names idea, feeling and quality. Examples:

(4) sùkù 'shame', yìdí ,love', nyitò, 'peace' ywàbè 'bitter', pwátfí 'anger', lalì 'happiness', mwahe 'beauty', ibè 'poverty'. 


\section{Compound Nouns}

These are nouns that are formed by joining two simple nouns. Examples are:

(5) a. ifit $+a+i y e ́=$ ifiaiye

b. $i m w a ̀+i b w i ́=i m w a i b w i$

'female'

c. $n \grave{i} \eta+t s i k \dot{u}=n \dot{t} \eta t s i k u$

'boy'

d. $n \dot{t} y+$ chì + nìn $=$ nìnchinìn

'pillow'

e. imwà+sahu =imwว̀sahu

'wealth'

f. ìní +na+si+nin =ininas̄inìn 'student"

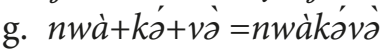
'teacher'

'clan'

\section{Pronouns}

There are several pronouns in Dzə. Some occur as subject and others as object pronouns. The following are the examples of pronouns found in Dza (Table 6, 7).

Table 6. Subject pronoun

\begin{tabular}{|c|c|c|}
\hline Person & Singular & Plural \\
\hline $1^{\text {st }}$ & $n$ 'I' & $b \grave{t}$ 'we' \\
\hline $2^{\text {nd }}$ & à 'you' & bà 'you' \\
\hline $3^{\text {rd }}$ & ò 'she/he' & è 'they/it' \\
\hline
\end{tabular}

Table 7. Object pronoun

\begin{tabular}{|c|c|c|}
\hline Person & Singular & Plural \\
\hline $1^{\text {st }}$ & mi 'me' & $b \grave{t}$ 'us' \\
\hline $2^{\text {nd }}$ & mà 'you' & bà 'you' \\
\hline $3^{\text {rd }}$ & wà 'her/him' & là 'them' \\
\hline
\end{tabular}

\section{Possessive Pronoun}

The possessive pronouns in Dzə are formed by adding a genitive marker " $a$ " before the object pronoun (singular) and the possessive morpheme " $v a$ " before an object pronoun (plural) (Table 8). Except for $3^{\text {rd }}$ person which is a subject pronoun.

Table 8. Possessive Pronoun

\begin{tabular}{|c|c|c|}
\hline Person & Singular & Plural \\
\hline $1^{\text {st }}$ & $\bar{a}^{-} m i$ 'mine' & àvá b’́ 'ours' \\
\hline $2^{\text {nd }}$ & 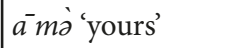 & àvá bà 'yours' \\
\hline $3^{\text {rd }}$ & a'o 'hers/his' & a'vá là 'theirs' \\
\hline
\end{tabular}




\section{Reflexive Pronoun}

The reflexive pronouns in Dzə are formed by prefixing a morpheme ' $k u$ ' which literally mean 'head' to the object pronouns. The $3^{\text {rd }}$ person singular uses object pronoun $w a$ when it comes to reflexive pronoun to when the prefix ' $k u$ ' is attached. See the table 9 below.

Table 9. Reflexive Pronoun

\begin{tabular}{|l|l|l|}
\hline \multicolumn{1}{|c|}{ Person } & \multicolumn{1}{c|}{ Singular } & \multicolumn{1}{c|}{ Plural } \\
\hline $1^{\text {st }}$ & $k u ́$ mi 'myself' & $k u ́$ b' 'ourselves' \\
\hline $2^{\text {nd }}$ & $k u ́$ ma'yourself' & $k u ́$ bà 'yourselves' \\
\hline $3^{\text {rd }}$ & $k u ́$ wà 'her/himself' & $k u ́$ l' 'their selves' \\
\hline
\end{tabular}

\section{Nouns and Pronouns as head of NP and their categories}

It is universally known that nouns and pronouns form the head of a noun phrase. This no different with Dzə. Noun phrase usually occurs with other elements which include determiners, numerals, genitives, modifiers, relative clauses, noun classifiers and the head noun $[2$, p. 86].

(6) $o$

3.SUB

'he came yesterday'.

(7) e-ije

PL-woman

'married women are proud'.

(8) $e$-ifi

PL-person

'people that crown king are coming'.

(9) mingbá ni di pi vado ni dé flood DET take place last time DET destroyed PL-house many 'the flood that happened last time destroyed many houses'.

(10) $b \grave{i}$

$\begin{array}{lllllll}b \grave{t} & f i & b a ́ & n \dot{t} & a & \text { wùka } & n \dot{t} \\ \text { 1SUB.PL } & \text { slaughter } & \text { goat } & \text { DET } & \text { 2.SUB } & \text { come } & \text { DET } \\ \text { 'we } & \text { slaughtered } & \text { the goat } & \text { you } & \text { brought. } & & \end{array}$

\section{Nominal Identification}

The following are the nominals in Dza that are identified based on syntactic criteria.

(11)
a. $\int^{\prime}$
$l \hat{e}$
'that pot'
pot
that 

b. $y \grave{i} \quad m \bar{i} \quad$ 'my brother'
brother my
c. $\stackrel{\dot{p}}{\dot{i}} \quad n \dot{t} \quad$ 'this hoe'
hoe this
d. chilika' iihyanin 'many fruits'
$\begin{array}{lll}\text { fruit many } & \\ \text { e. và } & a k \dot{a}\end{array} \quad$ large house'
house large

The lexical items appearing in the position where fà 'pot', $\tilde{p} \dot{\dot{t}}$ 'hoe', yì 'brother', va 'house' etc are consider nominals other categories cannot substitute them.

\section{Interrogative Pronouns}

Interrogatives pronouns in Dzə are:

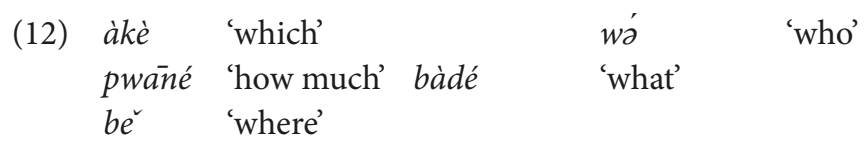

\section{Simple Noun Phrase}

Simple noun phrase is categorized by nouns and determiners such as articles, demonstratives, possessive pronouns, adjectives quantifiers (some, many, a few, each, and every) numerals. Demonstratives imply 'pointing to' or demonstrating [2, p. 103]. Consider the following.

\section{Articles}

There is only one type of article in Dzo and the definite articles. It is also used to mark agreement. Determiners can appear with both animate and inanimate, human and non-human entity. The definite article de can only be used when the noun has been mentioned before. And can occur both in the subject and object positions.

$\begin{array}{ll}\text { (13) và́káa } & \text { de } \\ \text { city } & \text { DET } \\ \text { the city' } & \\ \text { (14) } & \begin{array}{l}\text { bè } \\ \text { rope } \\ \text { the rope' }\end{array}\end{array}$

\section{Demonstratives}

Demonstratives can occur any where in the noun phrase except the pre-head position. They counld be proximal, medial or distal. 
(15)
a. kwàfi lê
e kwàfi
$l \hat{e}$
church that
PL kwə̀i
lê
'that church'
'those churches'

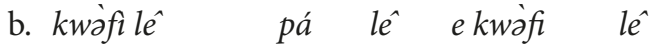 church that far that PL kwòfi lé
pá lê 'that far church'
'those far churches'
c. ká
tree
'this tree'
d. $b a ́$
goat
$n \bar{t}$
'this goat here'
$n \bar{t}$
this

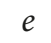
PL
these trees'
far that

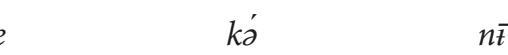

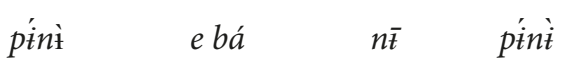
near PL goat this near
'these goats here'

\section{Possessives}

Possessives form parts of the determiners in Dzo noun phrase. They occur after the head noun in the phrase.

(16) $\dot{j}^{\prime}$

child

jí

child

jí

child

jí

child

jí

child $m i-$

my

$m \bar{a}$

your

bí

our

lé

their

wà

his/her 'my child'

'your child'

'our child'

'their child"

'his/her child'

\section{Adjectives}

(17)

\begin{tabular}{|c|c|c|}
\hline 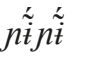 & fycni & 'small heart' \\
\hline heart & small & \\
\hline 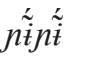 & $a k \dot{\tilde{a}}$ & 'large heart' \\
\hline heart & large & \\
\hline ni் & $h i l i$ & 'beautiful heart' \\
\hline heart & beauty & \\
\hline 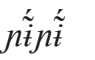 & àpìkán & 'good heart' \\
\hline heart & good & \\
\hline kwílit & nگ் & 'old heart"' \\
\hline
\end{tabular}




\begin{tabular}{|c|c|c|}
\hline old & heart & \\
\hline$b \grave{e}$ & $k \dot{u} k \dot{u}$ & 'short rope' \\
\hline rope & short & \\
\hline$b \grave{e}$ & àf & 'long rope' \\
\hline rope & long & \\
\hline$b \grave{e}$ & mwilí & 'heavy rope' \\
\hline rope & heavy & \\
\hline$b \grave{e}$ & jèfilay & 'light rope' \\
\hline$b \grave{e}$ & bwídzwádzwá & 'soft rope' \\
\hline rope & soft & \\
\hline$b \grave{e}$ & àtsá & 'hard rope' \\
\hline rop & hard & \\
\hline
\end{tabular}

\section{Numerals}

Numerals in Dzə like every other language are categorized into cardinal and ordinal. The cardinals start counting from one to five, it then changes numbering from six referring back to one. Six is 'sibling of one', seven is 'sibling of two' until the number ten. Eleven is referring back to ten which means 'ten sprang one, ten sprang two continue to fifteen. Reference is made to fifteen at sixteen which is fifteen sprang one continuous to twenty. From twenty upward to three hundred, reference is made to twenty. Thirty is twenty sprang ten, thirty-five is twenty sprang fifteen, forty is two twenties and that pattern continues. Example of cardinals are:

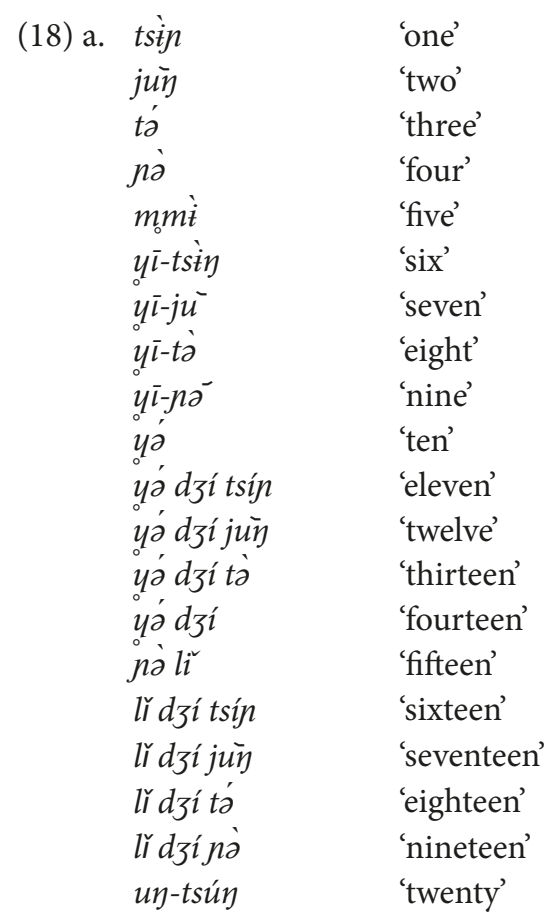


Their examples in noun phrase are as follows:

(19)
b. $\dot{e}$-ilày
bwató
PL-calabash
three
'three calabashes'
c. $\dot{e}-\int \dot{\partial}$
bwaná
PL-pot
four
'four pots'

Ordinals in Dzə are dependent on the genitive marker ' $a$ ' which is attached to the cardinal number except for the first and last which are ' $n w a t s i$ ' and 'tsítwà'. 'second' is a jún

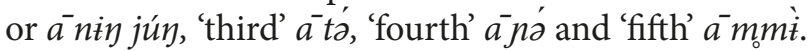

(20) a. jía

child GEN

'second child' nin jún

eye two

For nwatsí 'first', there is a lexical item na which literarily means 'hand' but tsítwà 'last' does not have that. So we can have:
b. $j \dot{t}$
child
na
nwatsí
'first child'
hand
first
c. jí tsítwá
child last

\section{Quantifiers}

Dzə quantifiers are parts of determiners in Dzə noun phrase and they occur after the head noun in a phrase. This study correponds with A. Lusekelo whose study in Nyakyusa noun phrase attests that determiners are post-nominal and is true for many other African languages [5, p. 306]. Consider:

$\begin{array}{lll}e \text {-ijè } & t s w a ̀ n \hat{t} & \text { 'few women' } \\ \text { PL woman } & \text { quant } & \\ e \text {-ìjè } & \text { ihyãnìy } & \text { 'many women' } \\ \text { PL woman } & \text { qaunt } & \end{array}$

Other universal quantifiers are listed below:

\begin{tabular}{|c|c|}
\hline$k \dot{e}$ & 'any/each \\
\hline$h^{\tilde{\varepsilon}}$ & ‘all' \\
\hline àkà & 'some' \\
\hline$t \sin ^{\prime} t \sin ^{\prime}$ & ‘each' \\
\hline
\end{tabular}

\section{Genitive constructions}

A possessive noun phrase contains two elements; a possessor and a possessed item. Sometimes the possessor is referred to as the genitives [2, p.104]. Like any other lan- 
guage, the genitive constructions in Dzo have both inalienable and alienable possession. The inalienable juxtaposed two nouns to show possession (possessee possessor). While the alienable use the genitive morpheme $v$ a to show possession (possessee genitive marker possessor).

\section{Inalienable Possessive}

$\begin{array}{lll}\text { (23) } n w a & \text { Esther } & \text { 'Esther's mouth' } \\ \text { mouth } & \text { Esther } & \\ \text { nin } & m i ́ & \text { 'my eye' } \\ \text { eye } & \text { my } & \\ \text { nə } & m i ́ & \text { 'my mother' } \\ \text { mothe } & \text { my } & \\ y \text { wá } & \text { Midafi } & \text { 'Midafi's stomach' } \\ \text { stomach } & \text { Midafi } & \\ t f \text { 'wi } & \text { Midafi } & \text { 'Midafi's neck' } \\ \text { neck } & \text { Midafi } & \\ \text { hywi } & \text { Midafi } & \text { 'Midafi's brother/sister' } \\ \text { brother } & \text { Midafi } & \end{array}$

The examples show the closesness between the possessee and the possessor. The possessees are not on their own but dependent on a larger entity or relation.

\section{Alienable Possessee}

Distance is created with the marker in between the possessees and the possessors.

(24) a. èmwaibwi disciples

Jesus's disciples'

b. ìdzwa vò dog GEN

'Nlabefi's dog'

c. dón dance GEN

'Nlabefi's dance'

$\begin{array}{ll}\text { và } & \text { Yeso } \\ \text { of } & \text { Jesus }\end{array}$

Nlabefi

Nlabefi

và

Nlabefi

Nlabefi

\section{Complex Noun Phrase}

S. M. Dryer states that a complex noun phrase contains more complex modifiers such as genitive or possessive construction and relative clauses, as in English London's mayor or the mayor of London [6]. The examples of complex noun phrases in Dza can be seen below. 
(25)

$\begin{array}{lll}\text { àpìkay } & \text { và } & \text { èifí } \\ \text { good } & \text { GEN } & \text { Pl-people }\end{array}$

'people's goodness/goodness of people

Adjectives are limited in Dzo. They have the ability to modify the head noun and they usually follow the noun. See the above examples.

\begin{tabular}{|c|c|c|}
\hline $\begin{array}{l}\text { nìyàbé } \\
\text { evil }\end{array}$ & $\begin{array}{l}\text { và } \\
\text { gen }\end{array}$ & $\begin{array}{l}\text { èifít } \\
\text { pl-people }\end{array}$ \\
\hline vil of people of & world' & \\
\hline
\end{tabular}

The head noun of the above example is nìnàbé 'evil' while the prepositional phrase và èifíf fàngwá of people world is its complement.

\section{Coordinative}

Dzo allows noun phrases that are formed by coordinating two noun phrases. That is additive coordination is present in the nominal system. The exampls are:

(27) a.
$k w a y$
tortoise
$b \grave{e}$
and
b. ntsilé
rabbit
$d \grave{e}$
DET
'the rabbit and spider'
ntsilé
rabbit

\section{nāndáy}
spider

The word $b i$ 'and' is a coordinator. It conjoins the two noun phrases ntsile dè 'the rabbit'and nāndáy 'spider' together. once the first NP contains the determiner de, the second NP do not need the definite article, sometimes there is no need of the definite article so long as it has been mentioned before in the conversation.

\section{Relative construction}

The relative marker $n \bar{t}$ is used in relative construction. Relative clauses in Dzə appear after the noun head in the phrase. The structure of the relative clause modifier is N. Rel.
$p \grave{\grave{i}}$
$n i$
$\grave{a}$
wàká
$n \grave{i}$
hoe
DEM
2suB
break
DEM

'the hoe that you broke'

$\begin{array}{llllll}\text { e-imwa } & d e & n i & \text { ngakə } & \text { keke nwa } & \text { nihyã } \\ \text { PL-children } & \text { DET } & \text { DEM } & \text { ride } & \text { bicycle mouth } & \text { road }\end{array}$

'the children who rode bicycles on the road'

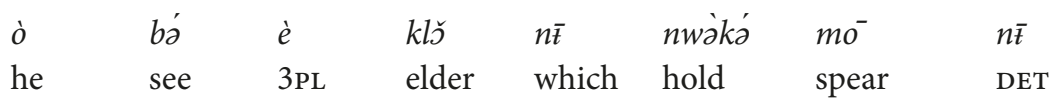

'he saw the elder who held the spear' 


$\begin{array}{llllllll}\text { imwaijè } & n \bar{t} & k u \check{\varepsilon} & v a & n \dot{t} & s i & n & y \text { winin } \\ \text { lady } & \text { who } & \text { sat } & \text { home } & \text { DET } & \text { LOC } & \text { NPST } & \text { cooking }\end{array}$

'lady who stayed home was cooking'

The word $n i$ is a relative pronoun, demonstrative pronoun and a completive depending on the context it is used. These relative pronouns are used to link or connect the noun (nominal) with the rest of the clause or phrase.

\section{Multiple NP extention}

Other NP extention in Dzə noun phrase may contain adjectives and other elements. Adjectives modify the head noun and almost always follow the head noun.

dàró àhu àpìkán
book new nice
'a new nice book'

Adjectives can co-occur as post-modifiers in Dzo. If this two adjectives co-occur, it is ungrammatical for àpìkáy 'nice/good' to appear before àhu 'new'. Àhu 'new' will always occur first in a phrase like this. Other examples are:

$\begin{array}{ll}\text { ijè àmwilì júmwahe } & \text { jù fat } \\ \text { woman beauty } \\ \text { 'a fat beautiful woman' }\end{array}$

\begin{tabular}{|c|c|c|c|}
\hline $\begin{array}{l}f^{\prime} \\
\text { pot }\end{array}$ & $\begin{array}{l}n \dot{t} \\
\text { DEM }\end{array}$ & $\begin{array}{l}\text { mwilí } \\
\text { large }\end{array}$ & $\begin{array}{l}\text { kànká } \\
\text { big }\end{array}$ \\
\hline \multicolumn{4}{|c|}{ 'that large big pot' } \\
\hline də̀ró & $n \bar{t}$ & tsín & kahye \\
\hline book & DEM & one & red \\
\hline
\end{tabular}

In (35), whatever the arrangement of adjectives after the head noun daro 'book', it is grammatical. But is more common to hear speakers place the ts'in 'one' before kahys 'red'. See also example (36) below.

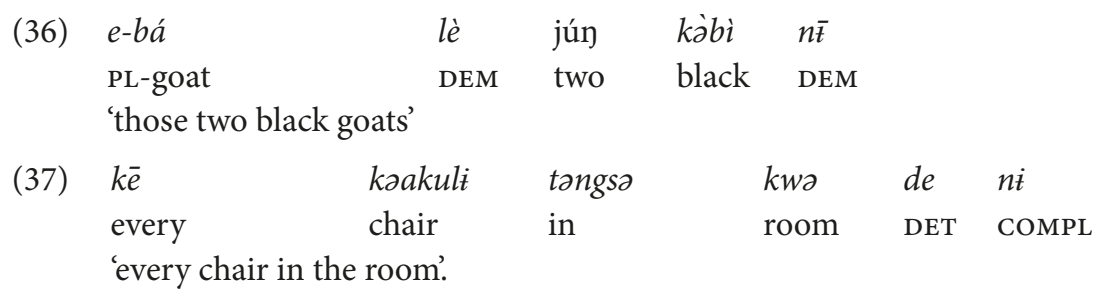

The phrase in (37) shows how NP can be extended in Dzo with the qualifiers. The determiner $k e^{-c}$ every' precedes the head noun kaakuli 'chair' $k e^{-}$selects only count nouns in Dzə. This agrees with M. J. Rugemalira [7] where distributive determiners of this kind 'each and every' are pre-nominal. This is one of the rare circumstances in Dzo where determiner precedes the head noun in a noun phrase that contains prepositional phrase. 

QUART PL-old man poss tall fat DET black DEM with leg bow 'each of those my five tall fat black men with bow legs'.

The plural can precede the adjective of age to show number agreement as in e kwi ibwi 'old men'. It means that adjectives can mark plurality in Dzo.

\section{Conclusion}

This study described the Dzə nouns and noun phrases. It demonstrated the different kinds of nouns and noun phrases. The elements that constitute noun phrase in Dzə ranges from determiners, possessives, demonstratives, numerals, and quantifiers. As expected, these elements are mostly post-modifiers. From the study, we understand that determiners are agreement markers in Dzə. This is just a preliminary study of the Dzo nouns and noun phrases. There is a lot that has not been looked into. There is a need for in-depth description of Dzo.

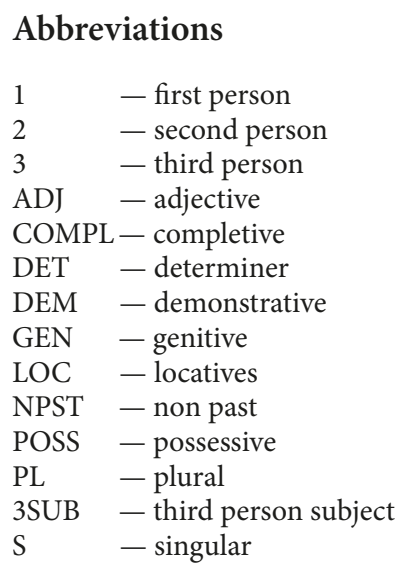

\section{References}

1. Givón T. Syntax. A functional-typological introduction, vol. I. Amsterdam; Philadelphia, John Benjamins, 1984. 464 p.

2. Payne E. T. Describing morphosyntax: A guide for field linguists. New York, Cambridge University Press, 1997. $413 \mathrm{p}$.

3. Radford A. English Syntax: An Introduction. Cambridge, Cambridge University Press, 2004. 384 p.

4. Othaniel N. K. Jenjo phonology statement. 2014. Unpublished manuscript.

5. Lusekelo A. The structure of the Nyakyusa noun phrase. Nordic Journal of African Studies, 2009, vol. 18 (4), pp. 305-331.

6. Dryer S.M. Noun phrase structure. Language typology and syntactic description, ed. T. Shopen. Cambridge, Cambridge University Press, 2007, pp. 151-205.

7. Rugemalira M.J. The structure of the Bantu noun phrase. SOAS Working Papers in Linguistics, 2007, vol. 15, pp. 135-148.

Author's information:

Peace Benson - peacebenson71@yahoo.com 


\section{Существительное и именная группа в языке джен}

\section{П. Бенсон}

Федеральный Университет Вукари, Нигерия, 1020, П.М.Б.

Для цитирования: Benson P. A Description of Dzə (Jenjo) Nouns and Noun Phrases, an Adamawa Language of Northeastern Nigeria // Вестник Санкт-Петербургского университета. Востоковедение и африканистика. 2020. Т. 12. Вып. 4. С. 490-504. https://doi.org/10.21638/spbu13.2020.402

Язык джен относится к семье адамава и распространен в некоторых районах штатов Тараба, Адамава и Гомбе Северо-Восточной Нигерии. Рассматриваются существительные и именные группы в языке джен. Поскольку джен недостаточно изучен и описан, статья предоставляет важные данные для типологических исследований и для лингвистов, работающих с языками адамава. Данные были получены в результате полевых исследований в декабре 2014 г., личных разговоров, наблюдений и изучения Библии на языке джен. Представлены краткий очерк фонологии и тонов языка джен, а также различные типы существительных, местоимений, простых и сложных именных групп. В языке джен много местоимений: личные, объектные, возвратные, вопросительные и притяжательные. Как и в большинстве других африканских языков, элементы, которые составляют именную группу, стоят после основного существительного. К таким элементам относят артикли, указательные и притяжательные местоимения, прилагательные, числительные, генитивы (притяжательные и непритяжательные) и определительные придаточные предложения. Эта статья - предварительное исследование языка джен, которое открывает путь для его дальнейшего изучения.

Ключевые слова: джен, существительные, именные группы, адамава, дженджо.

Статья поступила в редакцию 22 мая 2020 г., рекомендована к печати 21 сентября 2020 г.

Контактная информация:

Бенсон Пис — peacebenson71@yahoo.com 